\title{
PENGARUH DPR, FIRM SIZE DAN ROA TERHADAP DER (Studi pada Perusahaan Manufaktur Sektor Makanan dan Minuman yang Terdaftar di BEI Periode 2014-2018)
}

\author{
Galuh Candra Setianing Mutia ${ }^{1}$, Adi Rizfal Efriadi ${ }^{2}$ \\ ${ }^{1,2}$ Institute Teknologi dan Bisnis Ahmad Dahlan Jakarta \\ Jl. Ciputat Raya No.77, Cireundeu, Kec. Ciputat Timur, Kota Tangerang Selatan, Banten \\ 15419 \\ Email : adirizfalefriadi31@gmail.com
}

\begin{abstract}
The purpose of this study was to determine the effect of the dividend policy, firm size and profitability on the debt policy. This research design uses quantitative methods. The population of this research is the food and beverage sector manufacturing companies that have been and are still listed on the Indonesia Stock Exchange period 2014-2018. Sampling techniques using purposive sampling. The analytical method used is multiple linear regression. Based on the results of data analysis, dividend policy is not examined because the required data is incomplete and does not meet the requirements. Firm size has no effect on the debt policy. Profitability has a negative effect on the debt policy.
\end{abstract}

Keywords: debt to equity ratio (DER), dividend payout ratio (DPR), company size, profitability (ROA).

\section{PENDAHULUAN}

Pada perkembangan dunia bisnis sekarang ini, didirikannya suatu perusahaan memiliki bermacam-macam tujuan. Perusahaan dengan prinsip going concern, akan selalu mengembangkan operasinya, baik dari segi penjualan maupun produksi. Akan tetapi, tidak semua entitas memiliki dana yang cukup untuk hal tersebut. Hutang merupakan salah satu solusi dari ketidakmampuan perusahaan dalam mendanai pengembangan operasinya. Kebijakan pendanaan menyangkut aktivitas yang dilakukan untuk memperoleh dana dan menggunakan dana tersebut untuk mencapai tujuan perusahaan. Dana yang dimiliki atau diperoleh perusahaan digunakan sebagai modal sebagai penopang kegiatan usahanya. Salah satu kebijakan pendanaan perusahaan adalah penggunan dana external berupa hutang. Penggunan hutang ini akan diartikan oleh pihak luar tentang kemampuan perushaan untuk membayar kewajiban dimasa yan gakan datang. Besarnya nilai hutang dari setiap perusahaan berbeda-beda sesuai dengan kebijakan manajemen perusahaan masing-msing. Kebijakan hutang dapat diukur menggunakan long term debt rasio ( $L D E)$, dengan membandingkan total hutang 
dengan modal perusahaan. Debt equity rasio (DER) merupakan rasio yang digunakan untuk mengukur seberapa besar modal sendiri yang dibiayai oleh hutang.

Kebijakan deviden adalah keputusan apakah akhir laba yang diperoleh perushaan pada akhir tahun akan dibagikan dalam bentuk dividen atau dakan ditahan untuk menambah modal guna pembiayaan investasi di masa yang akan datang. Kebijakan terhadap deviden dapat mempengaruhi nilai perusahaan secara langsung maupun tidak langsung. Nilai perusahaan mencerminkan kemakmuran pemegang saham. Kebijakan deviden dapat diukur menggunakan indikator dividend payout rasio (DPR). Rasio ini dapat menggambarkan jumlah deviden perlembar saham yang dibagikan kepada pemegang saham terhadap laba per lembar saham.

Ukuran perusahaan merupakan karakteristik perusahaan yang dapat mengklasifikasikan apakah suatu perusahaan termasuk ke dalam ukuran perusahaan kecil, menengah, ataupun besar. Ukuran perusahaan menjadi faktor yang perlu dipertimbangkan dalam menentukan tingkat hutang perusahaan. Ukuran perusahaan dapat diukur dengan menggunakan firm size yaitu pengukuran dari Ln total asset perusahaan. Semakin besar ukuran suatu perusahaan akan semakin besar pula aktivitas yang dilakukannya dan dana yang dibutuhkan untuk operasionalnya juga semakin besar. Apabila sumber dana internalnya tidak mencukupi maka akan mencari sumber dana eksternal yaitu hutang.

Profitabilitas juga menentukan keputusan kebijakan hutang yang akan diambil oleh perusahaan. Profitabilitas adalah kemampuan suatu perusahaan dalam menghasilkan laba selama periode tertentu. Laba yang dihasilkan perusahaan berasal dari penjualan dan investasi yang dilakukan oleh perusahaan. Penelitian ini menggunakan pengukuran Return on Asset (ROA). ROA adalah pengukuran kemampuan perusahaan dalam mengelola asetnya untuk menghasilkan laba. Perusahaan dengan tingkat profitabilitas yang tinggi akan menggunakan hutang yang relatif kecil karena dengan tingkat pengembalian investasi yang tinggi perusahaan dapat melakukan permodalan dengan laba ditahan.

\section{RUMUSAN MASALAH}

1. Bagaimana pengaruh kebijakan deviden terdahap kebijakan hutang?

2. Bagaimana pengaruh ukuran perusahaan terhadap kebijakan hutang?

3. Bagaimana pengaruh profitabilitas terhadap kebijakan hutang?

4. Bagaimana pengaruh dari kebijakan deviden, ukuran perusahaan dan profitabilitas berpengaruh terhadap kebijakan hutang?

\section{TUJUAN PENELITIAN}

1. Untuk menganlisis pengaruh kebijakan deviden terhadap kebijakan hutang. 
2. Untuk menganlisis pengaruh ukuran perusahaan terhadap kebiakan hutang.

3. Untuk mengnalisis pengaruh profitabilitas terhadap kebijakan hutang.

4. Untuk menganalisis pengaruh kebijkaan deviden, ukuran perusahaan dan profitbilitas terhadap kebijakan hutang.

\section{LANDASAN TEORI}

\section{Packing Order Theori}

Teori ini menjelaskan mengenai urutan pendanaan yang dilakukan oleh perusahaan. Teori ini memprediksi bahwa perusahaan lebih cenderung mengutamakan dana internal daripada dana eksternal dalam aktivitas pendanaan. Pecking order theory melihat bahwa perusahaan cenderung memilih pendanaan sesuai dengan urutan risiko. Ide dasar teori ini sangat sederhana, yaitu perusahaan membutuhkan danaeksternal hanya apabila dan internal tidak cukup dan sumber dana yang diutamakan adalah hutang, bukan saham. Pecking order theory menjelaskan mengapa perusahaan yang sangat menguntungkan pada umumnya mempunyai utang yang lebih sedikit. Hal ini terjadi bukan karena perusahaan tersebut mempunyai target debt to equity ratio yang rendah, tetapi disebabkan perusahaan memangtidak membutuhkan dana dari pihak eksternal.

\section{Kebijakan hutang}

Kebijakan hutang adalah sebuah kepusan manajemen untuk menentukan pendanaan melalui hutang sebagai sumber pendanaan operasional suatu perusahaan. Kebijakan hutang diukur dengan rasio keuangan debt to equity rasio (DER).

\section{Kebijakan Deviden}

Kebijakan deviden adalah keputusan apakah akhir laba yang diperoleh perushaan pada akhir tahun akan dibagikan dalam bentuk dividen atau akan ditahan untuk menambah modal guna pembiayaan investasi di masa yang akan datang. Kebijakan terhadap deviden dapat mempegaruhi nilai perusahaan secara langsung maupun tidak langsung. Nilai perusahaan yang tinggi akan juga dapat mengidentifikasikan kemakmuran pemegang saham yang tinggi.

\section{Ukuran Perusahaan}

Ukuran perusahaan merupakan karakteristik perusahaan untuk mengklasifikasikan apakah suatu prusahaan termasuk ke dalam ukuran perusahaan kecil, menengah, ataupun besar. Semakin besar ukuran perusahaan akan semakin besar aktivitas yang dilakukan dan dana yang diperlukan akan seakin besar.

\section{Profitabilitas}


Pofitabilitas adalah kemampuan perusahaan untuk menghasilkan laba selama periode tertentu. Perusahaan dengan tingkat profitbilitas yang tinggi akan menggunakan hutang yang reatif lebih kecil. Dalam penelitian ini, menggunakan rasio pengukuran Return on Asset (ROA).

\section{PENELITIAN TERDAHULU}

a. Djabid (2009) menyimpulkan bahwa, kebijakan deviden tidak berpengaruh signifikan terhadap kebijkan hutang. Kepemilikan managerial dan kepemilikan institusinal tidak berpengaruh terhadap kebijakan hutang.

b. Syadeli (2013) menguji tentang struktur kepemilikan, profitabilitas dan ukuran perusahaan terhadap kebijakan hutang. Hasil pengujian menunjukkan profitabilitas berpengaruh negatif terhadap kebijakan hutang, ukuran perusahaan berpengaruh positif terhadap kebijakan hutang sedangkan strukur kepemilikan tidak berpengaruh tehadap kebijakan hutang.

c. Mardiyanti, Qothrunnada dan Kurnianti (2018) menyatakan bahwa kepemilikan manajerial dan struktur aktiva tidak berpengaruh terhadap kebijakan hutang yang diukur dengan DAR dan DER. Ukuran perusahaan berpengaruh positif terhadap kebijakan hutang menggunakan DER dan berpengaruh negatif terhadap kebijakan hutang menggunakan DAR. Pertumbuhan penjualan dan profitabilitas berpengaruh positif terhadap kebijkan hutang menggunakan DER dan tidak berpengaruh terhadap kebijakan hutang menggunakan DAR.

d. Rajagukguk dan Pakpahan (2017) menyatakan bahwa kebijakan deviden tidak berpengaruh terhadap kebijakan hutang, struktur aset berpengaruh positif terhadap kebijakan hutang dan pertumbuhan penjualan tidak perpengaruh terhadap kebijakan hutang.

\section{KERANGKA PEMIKIRAN}

Berdasarkan uraian teoritis dan hasil-hasil penelitian maka kerangka pemikiran dari penelitian ini adalah sebagai berikut:

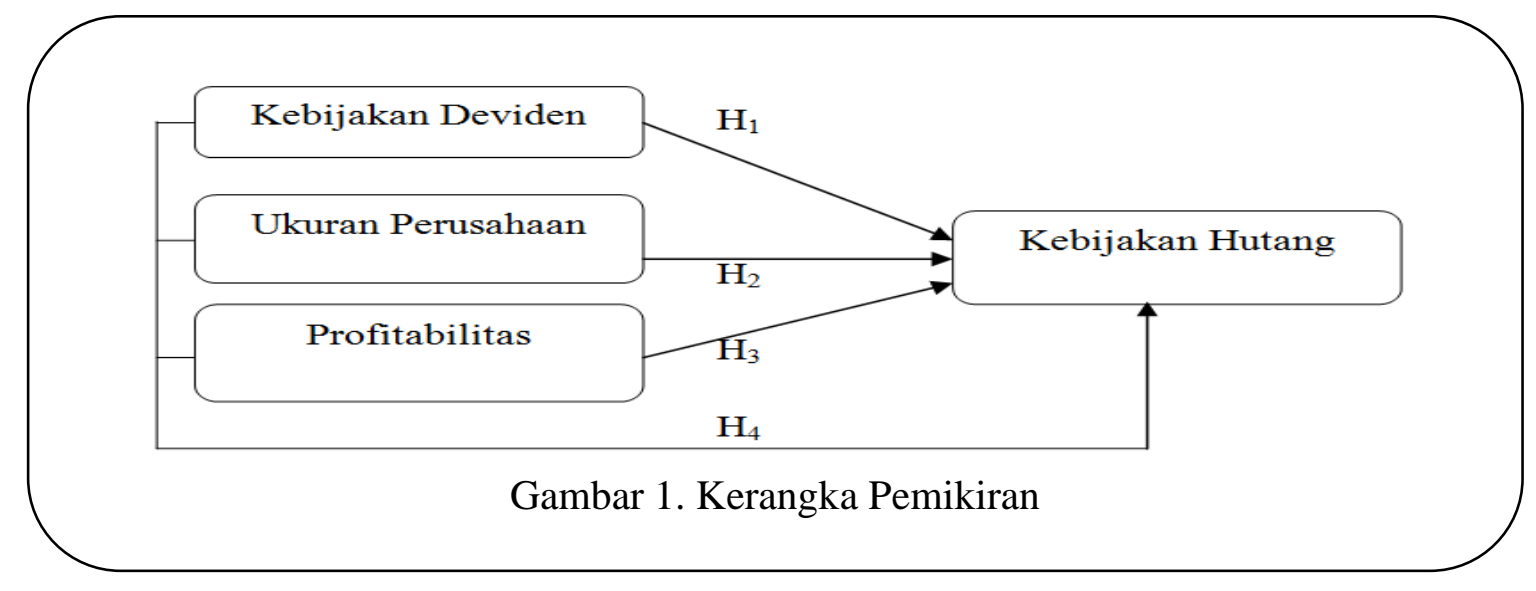




\section{HIPOTESIS}

$\mathrm{H}_{\mathrm{a} 1}$ : Kebijakan deviden berpengaruh terhadap kebijakan hutang

$\mathrm{H}_{\mathrm{a} 2}$ : Ukuran perusahaan berpengaruh terhadap kebijakan hutang

$\mathrm{H}_{\mathrm{a} 3}$ : Profitabilitas berpengaruh terhadap kebijakan hutang

$\mathrm{H}_{\mathrm{a} 4}$ : Kebijakan deviden, ukuran perusahaan dan profitabilias berpengaruh secara simultan terhadap kebijakan hutang

\section{METODE}

Populasi dari penelitian ini adalah perusahaan manufaktur sektor makanan dan minuman yang terdaftar di Bursa Efek Indonesia dari tahun 2014-2018. Metode pengambilan sampel menggunakan purposif sampling, dengan kriteria sebagai berikut: (1) perusahaan manufaktur sektor makanan dan minuman yang terdaftar berturut-turut di Bursa Efek Indonesia (BEI) dari tahun 2014-2018; (2) perusahaan tersebut memperoleh laba bersih secara berturut-turut selama periode 2014-2018 (3) perusahaan tersebut membagikan dividen selama periode 20142018.

\section{Pengukuran Variabel}

1. Variabel Independen

a. Kebijakan Deviden $\left(\mathrm{X}_{1}\right)$

Dalam penelitian ini, untuk mengukur kebijkan deviden digunaan dividend payout rasio. Deviden payour rasio adalah perbandingan antara deviden per lembar saham dengan laba per lembar saham. Rumus:

DPR $=\frac{\text { Deviden Per Lembar Saham }}{\text { Laba Per Lembar Saham }}$

b. Ukuran

Perusahaan $\left(\mathrm{X}_{2}\right)$

Ukuran perusahaan dapat diukur dengan menggunakan rumus:

$$
\text { FirmSize }=\text { LogTotal } \text { Asset }_{\text {it }}
$$

c. Profitabilitas $\left(\mathrm{X}_{3}\right)$

Dalam penelitian ini, menggunakan rasio pengukuran Return on Asset (ROA).

$$
\text { ROA }=\frac{\text { Laba Bersih Setelah PaJak }}{\text { Total Aktiva }}
$$

2. Variabel Dependen

Variabel terikat merupakan variabel yang dipengaruhi oleh variabel bebas. Variabel terikat dalam penelitian ini adalah kebijakan hutang (DER) yang merupakan perbandingan dari total hutang yang dimiliki perusahaan dengan 
total ekuitasnya. Rasio ini menunjukkan hubungan antara jumlah pinjaman jangka panjang yang diberikan kepada para kreditur dengan jumlah modal sendiri yang diberikan oleh pemilik perusahaan.

DER $=\frac{\text { Total Hutang }}{\text { Total Ekuitas }}$

\section{HASIL DAN PEMBAHASAN Statistik Deskriptif}

Tabel 1. Statistik Deskriptif

\begin{tabular}{|l|r|r|r|r|r|r|r|}
\hline & $\mathrm{N}$ & Minimum & Maximum & \multicolumn{1}{c|}{ Sum } & Mean & Std. Deviation & Variance \\
\hline Sizeit & 35 & 5.70 & 13.25 & 354.21 & 10.1203 & 2.76030 & 7.619 \\
\hline Roa & 35 & 0.03 & 0.18 & 2.95 & 0.0842 & 0.03996 & 0.002 \\
\hline Der & 35 & 0.16 & 1.53 & 29.63 & 0.8467 & 0.39245 & 0.154 \\
\hline
\end{tabular}

Sumber : Output SPSS yang Diolah, 2019.

Berdasarkan tabel 1. dapat diketahui bahwa pada perusahaan dibidang makan dan minuman yang menjadi sample pada penelitian ini dengan nilai ratarata Debt Equity Rasio (mean) sebesar 0,8467 pada standar devisiasi 0,3924. Nilai rata-rata tersebut lebih besar dari standar deviasi berarti bahwa sebaran nilai Debt Equity Rasio baik. Nilai rata-rata Sizeit sebesar 10,1203 pada standar devisiasi 2,76030. Nilai rata-rata (mean) lebih besar dari standar deviasi berarti bahwa sebaran nilai Sizeit baik. Nilai rata-rata profitabilitas sebesar 0,0842 pada standar devisiasi 0,03996. Nilai rata-rata (mean) lebih besar dari standar deviasi berarti bahwa sebaran nilai profitabiltas baik.

\section{Uji Asumsi Klasik}

\section{Uji Normalitas}

Tabel 2. Uji Normalitas Kolmogrov Smirnov

\begin{tabular}{|l|l|r|}
\hline \multicolumn{2}{|c|}{ One-Sample Kolmogorov-Smirnov Test } \\
\hline \multicolumn{2}{|c|}{} & \multicolumn{1}{|c|}{$\begin{array}{c}\text { Unstandardized } \\
\text { Residual }\end{array}$} \\
\hline $\mathrm{N}$ & Mean & 0.0000000 \\
\cline { 2 - 3 } $\begin{array}{l}\text { Normal } \\
\text { Parameters }\end{array}$ & $\begin{array}{l}\text { Std. } \\
\text { Deviation }\end{array}$ & 0.27693258 \\
\hline $\begin{array}{l}\text { Most Extreme } \\
\text { Differences }\end{array}$ & Absolute & 0.099 \\
\cline { 2 - 3 } & Positive & 0.062 \\
\cline { 2 - 3 } & Negative & -0.099 \\
\hline Test Statistic & 0.099 \\
\hline Asymp. Sig. (2-tailed) & $.200^{c, d}$ \\
\hline Sumber : Output SPSS yang Diolah, 2019 \\
\hline
\end{tabular}


Berdasarkan tabel 2. uji Kolomorov Smirnov menunjukkan bahwa data yang di dapat tersebut mengikuti distribusi normal, berdasarkan hasil output menunjukan nilai Kolmogorov-Smirnov signifikan pada 0,200 >0,05. Dengan demikian, residual data berdistribusi normal dan model regresi telah memenuhi asumsi normalitas.

\section{Uji Multikolinieritas}

Tabel 3. Hasil uji multikolinieritas

\begin{tabular}{|c|c|c|c|c|c|c|c|c|}
\hline & & $\begin{array}{r}\text { Unstanc } \\
\text { Coeff }\end{array}$ & $\begin{array}{l}\text { dized } \\
\text { nts }\end{array}$ & $\begin{array}{c}\text { Standardized } \\
\text { Coefficients }\end{array}$ & & & Collinearit) & atistics \\
\hline & del & B & $\begin{array}{l}\text { Std. } \\
\text { Error }\end{array}$ & Beta & $\mathrm{T}$ & Sig. & Tolerance & VIF \\
\hline 1 & (Constant) & 1.176 & 0.195 & & 6.016 & 0.000 & & \\
\hline & Sizeit & 0.027 & 0.018 & 0.192 & 1.489 & 0.146 & 0.938 & 1.066 \\
\hline & Roa & -7.183 & 1.265 & -0.732 & -5.680 & 0.000 & 0.938 & 1.066 \\
\hline
\end{tabular}

Berdasarkan tabel 3. diketahui bahwa nilai tolerance lebih dari 0,10 yaitu sebesar 0,938 sedangkan nilai VIF kurang dari 10,00 yaitu sebesar 1,066. Maka sesuai dengan dasar pengambilan keputusan dalam uji multikolinearitas dapat disimpulkan bahwa tidak terjadi gejala multikolinearitas.

\section{Uji Heterokedasitas}

Gambar 2. Scatterplot

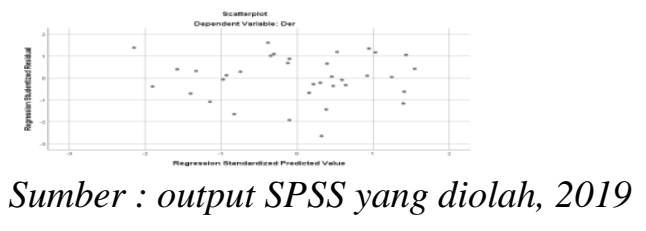

\section{Uji Autokolerasi}

Tabel 4. Runt Test

\begin{tabular}{|l|r|}
\hline & $\begin{array}{c}\text { Unstandardized } \\
\text { Residual }\end{array}$ \\
\hline Test Value $^{\mathrm{a}}$ & $.44364^{\mathrm{b}}$ \\
\hline Cases $<$ Test Value & 34 \\
\hline
\end{tabular}




\begin{tabular}{|l|r|} 
Cases $>=$ Test Value & 1 \\
\hline Total Cases & 35 \\
\hline Number of Runs & 3 \\
\hline Z & 0.000 \\
\hline Asymp. Sig. (2-tailed) & 1.000 \\
\hline \multicolumn{2}{|c|}{ Sumber : output SPSS yang diolah, 2019 } \\
\hline \multicolumn{2}{|c|}{}
\end{tabular}

Berdasarkan tabel 4. diketahui nilai signifikasi atau Sig. (2-tailed) sebesar 1,000 lebih besar dari dasar pengambilan keputusan yaitu sebesar 0,05 maka dapat disimpulkan tidak terdapat gejala autokolerasi.

\section{Uji Hipotesis}

\section{Uji T}

Tabel 5. Hasil uji t

\begin{tabular}{|c|c|c|c|c|c|c|}
\hline & & \multicolumn{2}{|c|}{$\begin{array}{c}\text { Unstandardized } \\
\text { Coefficients }\end{array}$} & \multirow{2}{*}{$\begin{array}{c}\begin{array}{c}\text { Standardized } \\
\text { Coefficients }\end{array} \\
\text { Beta } \\
\end{array}$} & \multirow[b]{2}{*}{$t$} & \multirow{3}{*}{$\frac{\text { Sig. }}{0.000}$} \\
\hline \multicolumn{2}{|c|}{ Model } & B & Std. Error & & & \\
\hline 1 & (Constant) & 1.176 & 0.195 & & 6.016 & \\
\hline & Sizeit & 0.027 & 0.018 & 0.192 & 1.489 & 0.146 \\
\hline & Roa & -7.183 & 1.265 & -0.732 & -5.680 & 0.000 \\
\hline
\end{tabular}

Berdasarkan tabel 5. di atas, dapat diketahui hasil analisis regresi diperoleh koefisien untuk variabel Sizeit sebesar 0,027 dan variabel profitabiltas sebesar 7,183 dengan nilai konstanta sebesar 1,176 sehingga model regresi yang diperoleh sebagaiberikut : $\mathrm{Y}=1,177+0,023-7,227$

Hasil uji pengaruh Sizeit terhadap Debt Equity Ratio menunjukan nilai t hitung 1,489 dan $\mathrm{p}$ value (Sig) sebesar 0,146 > 0,05. Artinya bahwa terdapat pengaruh namun tidak signifikan dari Sizeit (X2) terhadap Debt Equity Ratio (Y). Sedangkan, hasil uji pengaruh profitabilitas terhadap Debt Equity Ratio menunjukan nilai t hitung $-7,183$ dan $\mathrm{p}$ value (Sig) $0,000<0.05$. Artinya, adanya pengaruh profitabilitas (x3) terhadap Debt Equity Ratio.

\section{Uji F}

Tabel 6. Hasil uji F

\begin{tabular}{|c|c|c|c|c|c|c|}
\hline \multicolumn{2}{|c|}{ Model } & $\begin{array}{l}\text { Sum of } \\
\text { Squares }\end{array}$ & $\mathrm{df}$ & $\begin{array}{c}\text { Mean } \\
\text { Square }\end{array}$ & $\mathrm{F}$ & Sig. \\
\hline \multirow[t]{3}{*}{1} & Regression & 2.629 & 2 & 1.314 & 16.131 & $.000^{6}$ \\
\hline & Residual & 2.608 & 32 & 0.081 & & \\
\hline & Total & 5.236 & 34 & & & \\
\hline
\end{tabular}

Berdasarkan tabel 6. diketahui nilai Sig. adalah sebesar 0,000. Karena nilai Sig. $0,000<0,05$, maka sesuai dengan dasar pengambilan keputusan dalam uji $\mathrm{F}$ 
dapat disimpulkan bahwa variabel Sizeit dan Profitabilitas secara simultan berpengaruh tehadap Debt Equity Rasio. Diketahui nilai f hitung sebesar 16,131. Karena nilai $\mathrm{F}$ hitung 16,131 > F tabel 3,28, maka dapat disimpulkan bahwa variabel Sizeit dan Profitbilitas berpengaruh terhdap Debt Equity Rasio.

\section{Koefisien Determinasi $\left(\mathbf{R}^{2}\right)$}

Tabel 7. Koefisien Determinasi

\begin{tabular}{|l|l|r|r|r|}
\hline Model & $\mathbf{R}$ & $\begin{array}{c}\mathrm{R} \\
\text { Square }\end{array}$ & $\begin{array}{c}\text { Adjusted } \\
\mathrm{R} \\
\text { Square }\end{array}$ & $\begin{array}{c}\text { Std. } \\
\text { Error of } \\
\text { the } \\
\text { Estimate }\end{array}$ \\
\hline 1 & $.709^{\mathrm{a}}$ & 0.502 & 0.471 & 0.28546 \\
\hline
\end{tabular}

Sumber : output SPSS yang diolah, 2019

Berdasarkan tabel 7. diketahui nilai koefisien determinasi atau $\mathrm{R}$ square adalah sebesar 0,502 . Nilai $R$ Square 0,502 ini berasal dari pengkuadratan nilai koefisien kolerasi atau $\mathrm{R}$ yaitu $0,709 \times 0,709=0,502$. Besarnya angka koefisien determinasi atau $\mathrm{R}$ Square adalah 0,502 atau sama dengan 50,2\%. Angka tersebut mengandung arti bahwa variabel ukuran perusahaan $\left(\mathrm{x}_{2}\right)$ dan profitabilitas $\left(\mathrm{x}_{3}\right)$ secara simultan (bersama-sama) berpengaruh terhadap varibel Debt Equity Ratio (Y) sebesar 50,2\%. Sedangkan sisanya $(100 \%-50,2 \%=49,8 \%)$ dipengaruhi variabel lain diluar variable yang diteliti.

\section{Pembahasan Hasil Penelitian}

1. Pengaruh secara Parsial

a. Pengaruh Kebijakan Deviden terhadap Kebijakan Hutang.

Untuk variabel kebijakan deviden tidak diteliti karena daya yang digunakan dalam penelitian tidak memenuhi syarat dalam pengambilan sampel.

b. Pengaruh Ukuran Perusahaan terhadap Kebijakan Hutang.

Hasil penelitian statistik $\mathrm{t}$ untuk variabel ukuran perusahaan (sizeit) menunjukan nilai unstandardized beta coefficient sebesar 0,027 dengan nilai signifikasi 0,146 . Nilai signifikasi 0,146 lebih besar dari nilai signifikasi yang telah ditetapkan yakni $(0,05)$, maka variabel ukuran perusahaan (sizeit) tidak berpengaruh terhadap kebijakan hutang.

Penelitian ini tidak konsisten dengan Syadeli (2013), yang menyatakan bahwa ukuran perusahaan berpengaruh signifikan dan positif terhadap kebijakan hutang. Penelitian ini tidak menunjukkan pengaruh ukuran perusahaan terhadap kebijakan hutang disebabkan karena data perusahaan yang ada dalam penelitian ini merupakan perusahaan multinasional yang cenderung memiliki aset dan laba yang besar, karena memiliki segmen pasar yang luas. Sebagai perusahaan multinasional yang memiliki laba yng besar, perusahaan lebih memilih laba ditahan sebagai sumber pendanaan bagi perusahaan, karena memiliki risiko bisnis yang rendah. 
c. Pengaruh Profitabilitas terhadap Kebijakan Hutang.

Hasil penelitian statistik t untuk variabel profitbilitas (ROA) menunjukan nilai unstandardized beta coefficient sebesar $-7,183$ dengan nilai signifikasi 0,000. Nilai signifikasi 0,000 lebih kecil dari nilai signifikasi yang telah ditetapkan yakni $(0,05)$, maka variabel profitabilitas (ROA) berpengaruh negatif terhadap kebijakan hutang.

Penelitian ini konsisten dengan Syadeli (2013) dan Mardiyanti, Qothrunnada dan Kurnianti (2018) yang menyatakan bahwa profitabilitas berpengaruh terhadap kebijakan hutang. Hal ini disebabkan oleh perusahaan yang mempunyai laba lebih memilih menggunakan pendanaan internal yang lebih aman.

2. Pengaruh secara simultan

Ukuran perusahaan dan profitbilitas bersama-sama berpengruh terhadap kebijakan deviden.

\section{Kesimpulan}

Berdasarkan hasil penelitian data tentang kebijakan deviden, ukuran perusahaan, dan profitabilitas terhadap kebijakan hutang pada perusahaan manufaktur sektor makan dan minuman yang terdaftar di Bursa Efek Indonesia periode 2014-2018, dapat disimpulkan bahwa :

1. Kebijakan Deviden tidak memiliki pengaruh karena dalam penelitian ini data yang digunakan tidak diteliti.

2. Ukuran Perusahaan tidak berpengaruh terhadap kebiakan hutang, hal ini dibuktikan dengan nilai unstandardized beta coefficient sebesar 0,027 dengan nilai signifikasi 0,146 . Nilai signifikasi 0,146 lebih besar dari nilai signiffikasi yang telah ditetapkan yakni $(0,05)$.

3. Profitabilitas berpengaruh terhadap kebijakan hutang, hal ini dibuktikan dengan nilai unstandardized beta coefficient sebesar 0,027 dengan nilai signifikasi 0,146. Nilai signifikasi 0,146 lebih besar dari nilai signiffikasi yang telah ditetapkan yakni $(0,05)$.

4. Ukuran Perusahaan dan Profitabilitas berpengaruh secara simultan (bersama-sama) terhadap Kebijakan Hutang, hal ini dibuktikan dengan nilai Sig. adalah sebesar 0,000. Karena nilai Sig. 0,000 $<0,05$ dan nilai $\mathrm{f}$ hitung sebesar 16,131. Karena nilai F hitung 16,131 > F tabel 3,28. 


\section{Daftar Pustaka}

Abdullah W. Djabid. 2009. Kebijakan Dividen Dan Struktur Kepemilikan Terhadap Kebijakan Hutang: Sebuah Perspektif Agency Theory. Jurnal Keuangan Dan Perbankan, Vol. 13 No. 2 Mei 2009: 249-259.

Brigham, F. Eugene dan Joel F. Houston. 2012. Fundamental of Financial Management (Dasar-Dasar Manajemen Keuangan) Edisi 11 Buku. Jakarta: Salemba Empat.

2013. Fundamental of Financial Management (Dasar-Dasar Manajemen Keuangan) Edisi 12 Buku. Jakarta: Salemba Empat.

Fahmi, Irhan. 2013. Analisis Laporan Keuangan. Bandung: Alfabeta.

Ghozali, Imam. 2014. Aplikasi Analisis Multivariate Dengan Program IBM SPSS. Semarang: Universitas Diponegoro.

Irvan Riska Fauzi. 2017. Pengaruh Kepemilikan Manajerial, Ukuran Perusahaan, Kebijakan Deviden dan Profitabilitas Terhadap Kebijakan Hutang Pada Perusahan Manufaktur Yang Terdaftar Di Bursa Efek Indonesia. Skripsi Universitas Negeri Yogyakarta.

Lasmanita Rajagukguk, dan Yunus Pakpahan. 2017. Analisis Pengaruh Kebijakan Deviden, Struktur Asset, dan Pertumbuhan Penjualan Terhadap Kebijakan Hutang Pada Perusahaan Manufaktur Yang Terdaftar Di Bursa Efek Indonesia Tahun 2011-2015. Jurnal Akuntansi Vol. 17, No. 1, Januari 2017.

Moh. Syadeli. 2013. Struktur Kepemilikan, Profitabilitas Dan Ukuran Perusahaan Terhadap Kebijkan Hutang Perusahaan Manufaktur Di Bursa Efek Indonesia. Jurnal Management dan Akuntansi Vol. 2, No. 2. Agustus 2013. STIE Malangkucecara Malang.

Sudana, I Made. 2013. Manajemen Keuangan Peusahaan. Edisi 2. Jakarta: Erlangga.

Suwarjono. 2014. Teori Akuntansi Perekayasaan Pelaporan Keuangan. Edisi 1. Yogyakarta: BPFE Yogyakarta.

Tatang Ary, Gumantri. 2013. Kebijakan Deviden: Teori, Empiris dan Implikasi. Edisi 1. Yogyakarta: UPP STIM YKPN

Umi Mariyanti, Qothunnada \& Destria Kurnianti. 2018. Pengaruh Kepemilikan Manajerial, Struktur Aktiva Ukuran Perusahaan, Pertumbuhan Penjualan dan Profitabilitas Terhadap Kebijakan Hutang Pada Perusahaan Sektor Aneka Industri Yang Terdaftar Di Bursa Efek 
Kompartemen: Jurnal Ilmiah Akuntansi/Maret 2018, XVI(1), 1-20

Indonesia Periode 2012-2016. Jurnal Riset Manajemen Sains Indonesia Vol. 9, No. 1, 2018.

WwW.Idnfinancials.com 